\title{
VYBRANÉ EVOLUČNÍ TEORIE PROCESU INTERNACIONALIZACE PODNIKATELSKÝCH AKTIVIT
}

\author{
Šárka Zapletalová
}

\section{Klíčová slova:}

Internacionalizace, internacionalizační teorie, podnikatelské aktivity, Uppsalský model, evoluční přístup, globální prrístup, I-modely.

\section{Key words:}

Internationalization, internationalization theory, entrepreneurial activities, Uppsala model, evolutionary approach, global approach, I-models

\begin{abstract}
Abstrakt
Internacionalizace podnikatelských aktivit je fenomén, na který se pohlíží v posledním období $\mathrm{z}$ různých pohledů. Internacionalizace je nezbytná pro většinu podnikatelských subjektů. Článek se zabývá procesem internacionalizace podnikatelských aktivit. Cílem článku je podat přehled nejvýznamnějších internacionalizačních teorií.
\end{abstract}

\begin{abstract}
Internationalization is a phenomenon researched intensively over the last few decades from a variety of viewpoints. Internationalization of entrepreneurial activities is the necessity for majority of entrepreneurial subjects. This article inquire into the internationalization process of entrepreneurial activities. The objective of this paper is to present the overview of the most important internationalization theories.
\end{abstract}

\section{Úvod}

Podnikatelský subjekt, který uplatňuje strategii růstu, si dříve nebo později uvědomí nutnost rozvoje podnikatelských aktivit, expanzi podnikatelských aktivit, nejen na tuzemském, ale i na zahraničním trhu. Geografické šíření (rozšíření) podnikatelských aktivit přes národní hranice státu se nazývá internacionalizace podnikatelských aktivit. Tento odborný termín se začal používat ve dvacátých létech 20. století, kdy tento fenomén postupně nahradil imperialismus jako dominantní organizační princip formující přeshraniční vztahy mezi ekonomikami. V systémovém kontextu, je internacionalizace chápána jako „kumulativní proces, ve kterém vztahy (styky) jsou kontinuálně stanovené, udržované, rozvíjené, přerušované a rozpuštěné za účelem dosažení cílů firmy“. [Ruzzier, 2006]

\section{Internacionalizační teorie}

Problematika internacionalizace podnikatelských aktivit se stala předmětem zkoumání řady renomovaných ekonomů, kteří se podíleli a podílí na formulování internacionalizačních teorií. V rámci studia internacionalizačních teorií můžeme identifikovat přístup evoluční a př́istup globální.

Evoluční přístup $\mathrm{k}$ internacionalizaci podnikatelských aktivit předpokládá, že podniky postupují při internacionalizaci po určitých etapách, krocích. Internacionalizace podniku se tak jeví jako postupný proces akumulace potřebných zdrojů nutných k překonání nejistot na mezinárodních trzích. Tyto teorie (modely) předpokládají, že podniky rostou a sílí na tuzemském trhu a až poté začínají rozvíjet své exportní aktivity. Znalosti a zdroje jsou 
postupně získávány prostřednictvím zkušeností prvotně na tuzemském trhu a později na trhu mezinárodním. [Lopez, 2009] Khlavním představitelům evolučního př́stupu $\mathrm{k}$ internacionalizaci podnikatelských aktivit patří Model Uppsalské školy a I-model. Oba tyto modely vycházejí z behavioristických teorií.

Ale ne všechny podniky odpovídají etapovému modelu. Tyto podniky jsou ve své orientaci mezinárodní již od svého vzniku. Hovoříme o fenoménu tzv. globálně narozených podniků (born-globals). [Lopez, 2009] To znamená, že podniky začínají s internacionalizačními aktivitami v momentě jejich vytvoření a to potvrzuje, že podniky jsou schopné proniknout na trhy, které jsou daleko jak geograficky nebo psychicky, navzdory omezených zdrojů a malých akumulací organizačního učení. U těchto podniků probíhají internacionalizační procesy rychleji než je obvyklé u podniků podobné velikosti, stáŕí a povahy.

\section{Model Uppsalské školy}

Tradiční teorie internacionalizace podnikatelských aktivit nejčastěji vycházejí z teorie Uppsalské školy. Model Uppsalské školy, nazývaný také jako U-model, byl zformulován výzkumnými pracovníky z Uppsala Univerzity ve Švédku v 70. letech 20. století. Hlavními výzkumníky, kteří se podíleli na formulaci teorie byl Jan Johanson, Finn Wiedersheim-Paul a Jan-Erik Vahlne.

Základními předpoklady modelu Uppsalské školy je, že firma se snaží o růst dlouhodobého zisku, který je ekvivalentní k růstu. Firma také se snaží o udržení rizika na nízké úrovni. Model dále přepokládá, že průběh internacionalizace ovlivňují vnímané př́ležitosti a rizika, která obráceně ovlivňují rozhodnutí o tržním úsilí a současných aktivitách. [Johanson, 1977]

Model byl vytvořen na základě empirického pozorování a analýzy procesu internacionalizace čtyřech švédských firem: Sandvik, Atlas Copco, Facit a Volvo. První závěry z tohoto pozorování formulovali J. Johanson a F. Wiedersheim-Paul v roce 1975. Na základě pozorování vybraných švédských firem byly vysloveny základní předpoklady, východiska související s internacionalizací podnikatelských aktivit.

Základním předpokladem podle autorů [Johanson, 1975] je, že firmy nejprve rozvíjejí své podnikatelské aktivity na tuzemském trhu a že internacionalizace podnikatelských aktivit je důsledek série krokových rozhodnutí vedení podniku. Významnými překážkami internacionalizace podnikatelských aktivit je nedostatek znalostí o zahraničních trzích a podnikových zdrojů. Tyto překážky mohou být redukovány prostřednictvím krokového rozhodování a učení o zahraničních trzích a operacích.

Dalším předpokladem U-modelu je, že podniky na jednotlivých zahraničních trzích postupně, krokově rozšiřují své operace. Počet fází a jednotlivé typy operací se mohou na jednotlivých trzích lišit. Výzkumníky byly určeny čtyři odlišné fáze procesu internacionalizace podnikatelských aktivit. Uvedené fáze byly vybrány jednak proto, že jsou odlišné vzhledem k stupni zapojení firem na trhu a také proto, že jsou nejčastěji uváděny odborníky pracujícími v oblasti mezinárodního podnikání. [Johanson, 1975]

1. Nepravidelné exportní aktivity - nepravidelné exportní aktivity jsou typické pro firmy, které nemají vytvořeny žádné zdrojové vazby k trhu nebo nemají dostatek znalostí o zahraničních trzích nebo mají tendenci vyhýbat se nejistotě. Ve většině případů firmy začínají exportováním do sousedních zemí nebo zemí, které jsou poměrně dobře známé a podobné s ohledem na obchodní praktiky. 
2. Export přes nezávislé reprezentanty (agenty) - firmy si vytvářejí určité vazby (informační a distribuční) na zahraniční trh prostřednictvím nezávislých reprezentantů, agentů. Nezávislí reprezentanti jsou obstojným zdrojem pravidelných informací o situaci zahraničních trzích a zároveň jsou méně náročnějšími na zdroje než zajištění vlastního prodeje $\mathrm{v}$ zahraničí. $\mathrm{V}$ rámci zprostředkovatelské fáze si firmy vytváŕejí exportní oddělení, které je zodpovědné za vyhledávání a udržování nezávislých reprezentantů.

3. Prodejní dceřiné společnosti - založení dceřiné společnosti na zahraničních trzích je mimo jiné stimulováno růstem potřeby kontroly prodeje na zahraničních trzích a růstem poptávky na zahraničních trzích. Během této fáze internacionalizace si firma vytváří kontrolovatelné informační kanály na zahraničním trhu, které dávají schopnost firmě přímo řídit typ a množství informací plynoucích z trhu $\mathrm{k}$ firmě a $\mathrm{z}$ firmy směrem $\mathrm{k}$ trhu. Tímto řízením informačních toků firma může prrímo ovlivňovat faktory působící na prodej na zahraničních trzích.

4. Výroba/produkce - firma zakládá svoji výrobu přímo na zahraničních trzích. Ustanovení produkce na zahraničních trzích je ovlivněno různými faktory, především psychickou vzdáleností, celními a necelními bariérami a také transportními náklady. V této fázi je nutná koordinace produkční a marketingové činnosti na jednotlivých zahraničních trzích.

Výše uvedené čtyři fáze představují postupné zvyšování nároků na zdroje a také ukazují postupné získávání tržních zkušeností a informací ze zahraničních trhů důležitých pro firmu jak ukazuje Schéma 1. Tyto fáze v procesu internacionalizace podnikatelských aktivit jsou závislé na rozvoji znalostních aktivit a na organizační struktuře firmy. Posloupnost fází je nazývána Johansonem a Wiedersheim-Paulem [Johanson, 1975] jako ustavující řetězec. Nelze očekávat, že firmy vždy projdou celým řetězcem. Skoky v ustavujícím řetězci lze předpokládat především v situaci nedostatečného tržního potenciálu daného zahraničního trhu nebo v př́ípadě firem s rozsáhlými zkušenostmi z jiných zahraničních trhů.

Neopomenutelným faktorem je podle autorů [Johanson, 1975] v procesu internacionalizace podnikatelských aktivit působení tzv. psychické vzdálenosti. Koncepce psychické vzdálenosti je chápána jako vlivy chránící nebo bránící toku informací mezi firmou a zahraničním trhem. Mezi tyto vliv patři především odlišnosti v jazyce, v kultuře, v politických systémech, v úrovni vzdělání, v úrovni průmyslového rozvoje apod. V procesu internacionalizace podnikatelských aktivit se koncepce psychické vzdálenosti projevuje v tom, že firmy začínají své operace v zemích, které jsou geograficky blízké, a tudíž mají stejné podnikatelské prostředí.

Model Uppsalské školy, vytvořený v roce 1975, byl rozvinut J. Johansonem a J.-E. Vahlnem v roce 1977 [Johanson, 1977] o integraci a užití znalostí o zahraničních trzích a operacích a na postupné úsilí na zahraničních trzích. Hlavním východiskem tohoto rozvinutého modelu je nedostatek takových znalostí, které se stávají významnými překážkami k rozvoji mezinárodních operací a takových nezbytných znalostí, které mohou být získány především prostřednictvím operací na zahraničních trzích.

Hlavní struktura modelu je daná odlišnostmi mezi stavovými a změnovými aspekty internacionalizačních proměnných, viz. Schéma 2.

Za stavové aspekty jsou považovány zdroje tržního úsilí a tržní znalosti (znalosti o zahraničních trzích a operacích). Tržní úsilí je ovlivněno vnímáním př́íležitostí a rizik každou firmou. Tržní úsilí je dáno dvěma faktory, a to množstvím zapojených zdrojů (investice pro konkrétní trhy) a stupněm zapojení. V Modelu Uppsalské školy můžeme rozlišit několik 
druhů tržních znalostí. Podle účelnosti znalostí, můžeme rozdělit znalosti na znalosti potřebné k zahájení rozhodování a na znalosti potřebné k hodnocení alternativ. Dále můžeme tržní znalosti rozdělit podle toho, jak byly získány na znalosti zkušenostní a znalosti objektivní. Tržní znalosti můžeme také rozlišit podle jejich charakteru na znalosti obecné a znalosti tržně specifické. Vzhledem k tomu, že tržní znalosti jsou považovány za zdroje, definujeme vztah tržního úsilí a tržních znalostí jako přímý. Čím lepší máme znalosti o trhu tím, je úsilí o trh silnější.

Změnové aspekty jsou rozhodnutími o zdrojích úsilí a realizaci současných obchodních aktivit. Změnové aspekty v modelu tvoří současné obchodní aktivity a rozhodnutí o zdrojích tržního úsilí pro zahraniční operace. Současné obchodní aktivity jsou mimo jiné primárním zdrojem zkušeností. V internacionalizačním procesu rozlišujeme mezi firemními zkušenostmi a tržními zkušenostmi, oba tyto typy zkušeností jsou nezbytné.

Druhým změnovým aspektem je rozhodnutí o zdrojích tržního úsilí pro zahraniční operace. Rozhodnutí o zdrojích tržního úsilí závisí na tom, jaké alternativy vybíráme a jak vnímáme problémy a/nebo příležitosti na trhu. Vnímané problémy a př́iležitosti na trhu jsou závislé na zkušenosti firmy.

Tržní znalosti a tržní úsilí jsou předpokladem k ovlivnění jak rozhodnutí o úsilí tak způsob výkonu současných aktivit. A naopak rozhodnutí o úsilí a výkonu současných aktivit ovlivňuje tržní znalosti a tržní úsilí.

\begin{tabular}{|l|l|}
\hline Stavové aspekty & Změnové aspekty \\
\hline Tržní znalosti & Rozhodnutí o úsilí \\
\hline Tržní úsilí & Současné aktivity \\
\hline
\end{tabular}

Schéma 1 Základní mechanismus internacionalizace v modelu Uppsalské školy z roku 1977 Zdroj: [Johanson, 2009]

Vztah mezi znalostí trhu a úsilím o trh se budují v čase a jsou tedy klíčovým hnacím motorem internacionalizace. Zkušenost podniku postavená na znalosti trhu ovlivňuje úsilí a aktivity podniku na zahraničních trzích. Rostoucí úsilí pak podporuje rozvoj znalosti trhu. Právě z důvodu těchto vazeb je model Uppsalské školy z roku 1977 dynamický. [Johanson, 1977, 2009] To znamená, že výsledky jednoho rozhodnutí ustanovují vstup do nového rozhodnutí. Jinak řečeno, současný stav internacionalizace je jedním významným faktorem vysvětlujícím průběh následujícího kroku internacionalizace.

Model Uppsalské školy z roku 1977 byl autory revidován v roce 2009 do modelu business network model [Johanson, 2009]. Ačkoliv základní struktura modelu je stejně postavená jako v modelu z roku 1977, byly provedeny některé nepatrné změny. V revidovaném modelu má firma ústřední místo v obchodní síti. Firma není chápán jako samostatný subjekt bez vazeb.

Model 2009 tvoři dvě sady aspektů, stejně jako model z roku 1977, a to stavové a změnové. Jednotlivé aspekty byly upravené, oproti původnímu modelu, na základě změn podnikatelského prostředí.

Do skupiny stavových aspekti̊ byly zařazeny znalosti, př́ležitosti a pozice $\mathrm{v}$ systému. [Johanson, 2009] Ke konceptu znalosti byly přidány příležitosti, které představují velmi důležitý prvek soustavy znalostí. Prvek znalosti obsahuje také potřeby, schopnosti, strategie a 
systémy př́mo nebo nepřímo týkající se podniku v jeho institucionálním kontextu. Prvek pozice $\mathrm{v}$ systému, v původním modelu označován jako tržní závazek úsilí, byl takto přejmenován vzhledem $\mathrm{k}$ předpokladu, že internacionalizační proces podniku probíhá v určitém systému obchodních vztahů.

Skupina změnových aspektů, které ovlivňují další, patří vztahy při rozhodování o závazku, učení, vytváření, budovaní důvěry. [Štrach, 2009];

\begin{tabular}{|l|l|}
\hline Stavové aspekty & \multicolumn{2}{|l|}{$\begin{array}{l}\text { Změnové aspekty } \\
\text { Přlosti }\end{array}$} & $\begin{array}{l}\text { Vztahy při } \\
\text { rozhodování o úsilí }\end{array}$ \\
\hline Pozice v systému & $\begin{array}{l}\text { Učení } \\
\text { Vytváŕení } \\
\text { Budování důvěry }\end{array}$ \\
\hline
\end{tabular}

Schéma 2 Internacionalizační proces v obchodním systému v modelu Uppsalské školy z roku 2009 Zdroj: [Johanson, 2009]

Revize modelu přinesla pro internacionalizační proces několik důsledků. Internacionalizace podniku závisí na jeho vztazích v systému. Podle Johansona [Johanson, 2009] můžeme předpokládat, že ústřední firma vstupuje na zahraniční trhy na základě svých vztahů s významnými partnery, kteří rozvíjejí své aktivity na zahraničních trzích. Tito partneři mohou být z tuzemska nebo ze zahraničí. Ústřední firma pravděpodobně následuje a drží se svého partnera, jestliže má vybudovanou hodnotnou pozici na zahraničních trzích.

Pro firmu existují, z tohoto pohledu, dva hlavní důvody pro expanzi na zahraniční trhy. Jedním z nich je nalezení zajímavé obchodní příležitosti partnerem. Znalosti partnera jsou vzájemně propojené s ostatními členy, a tak se nepřímo týkají ostatních členů systému. Ostatní členové systému se spoléhají na příslušné znalosti ostatních partnerů, které jsou schopni se naučit a využívat obchodní př́ležitosti. Druhým důvodem k expanzi nastává v případě, kdy obchodní partner firmy se rozhodne expandovat na zahraniční trhy a firma se jej rozhodne následovat. Následování partnera je určitou demonstrací jejich vzájemných vztahů a závazků. [Johanson, 2009]

Firma následuje svého obchodního partnera na takový trh, ve kterém má partner silnou obchodní pozici a má podnikatelské př́ležitosti. A takto jej firma může následovat z trhu na trh. Jestliže obchodní partner firmy nemá na zahraničních trzích silnou pozici, tak se firma rozhoduje o spojení s novým partnerem reprezentujícím určitou pozici na zahraničním trhu. Př́ípadně si firma vybuduje pozici na zahraničním trhu např́ílad vytvořením své vlastní dceřiné společnosti. V tomto případě si firma volí trhy s krátkou psychickou blízkostí, kde je jednodušší vytvářet a rozvíjet nové obchodní vztahy. [Johanson, 2009] Vstup firmy na trh nezávisle na partnerech je umožněn růstem znalostí nebo nespokojeností firmy se vztahy s dalšími partnery.

\section{I-modely}

Modely internacionalizace podnikatelských aktivit související s inovací (nazývané také jako Imodely) zahrnují modely, které vysvětlují internacionalizační proces z pohledu inovací. [Andersen, 1993] Termín ,innovation-related“ je odvozen z práce Rogers Diffusion of 
Innovations (1962), ve kterém každé internacionalizační rozhodnutí je považováno za inovace pro firmu. [Ruzzier, 2006] Tyto modely jsou založeny na postupném učení (postupnosti učení) v souvislosti s (ve spojení s) adaptací inovací. I-modely stejně jako U-model vychází z behavioristických teorií. Modely zahrnuté do skupiny I-modely vysvětlují především vývoj exportních aktivit $\mathrm{v}$ malých a středních podnicích.

I-modely jsou reprezentovány stupni, kde vyšší stupeň reprezentuje větší zkušenosti/zapojení než nižší stupeň. Posloupnost pořadí jednotlivých kroků závisí mimo jiné na iniciační fázi procesu (push, pull mechanismus). V iniciační fázi mohou působit jak push mechanismy tak pull mechanismy. Všechny modely vykazují řadu společných rysů. Hlavními rozdíly mezi těmito modely je v počtu stupňů a popisu jednotlivých stupňů. I když rozdílnosti jednotlivých modelů někdy spočívají spíše $\mathrm{v}$ sémantických rozdílech než ve skutečných rozdílech v povaze internacionalizačního procesu.

Do I-modelů patří modely autorů [Morgan, 1997; Andersen, 1993]:

- W. J. Bilkey a G. Tesar (1977) chápou proces vývoje exportu na základě růstu exportního zapojení firmy směrem k psychologicky vzdálenějším trhům. Jejich proces internacionalizace podnikatelských aktivit je tvořen šesti fázemi, a to:

○ management se nezajímá o export

○ management je ochoten splnit nevyžádané objednávky, ale nechce vynakládat žádné úsilí k vyhledání uskutečnění aktivního exportu

- management aktivně vyhledává uskutečnění aktivního exportu

- firmy exportují na experimentální bázi do některých psychologicky blízkých zemí

○ firma je zkušený exportér

- management vyhledává uskutečnění exportu do dalších zemí psychologicky vzdálenějších

- S. T. Cavusgil (1980) předpokládá proces vývoje exportních aktivit založený na postupném rozhodování managementu s ohledem na časový interval a na empirických poznatcích. Tento proces internacionalizace je tvořen těmito pěti fázemi:

○ tuzemský marketing: firma prodává pouze na tuzemském trhu

○ předexportní zapojení: firma hledá informace a hodnotí uskutečnění exportního podnikání

- experimentální exportní zapojení: firma začíná exportovat na omezeném základě do psychologicky blízkých zemí

- aktivní exportní zapojení: exportování do více nových zemí - přímé exportování - růst prodejního objemu

○ angažované exportní zapojení: management pravidelně vybírá v přidělení omezených zdrojů tuzemskými a zahraničními trhy

- S. D. Reid (1981) předpokládá, že přijetí rozhodnutí o realizaci exportních aktivit vyžaduje př́iznivé postoje managementu $\mathrm{k}$ exportu, dosažitelné př́ležitosti na zahraničních trzích a přítomnost rezervních zdrojových kapacit ve firmě. Reid pojímá inovaci následujícími pěti fázemi:

○ exportní povědomí (uvědomění si exportu): problém rozpoznání příležitosti, probuzení potřeby

- exportní plán: motivace, postoje, názory a očekávání exportu

○ vyzkoušení exportu: vlastní zkušenost z omezeného exportu

○ hodnocení exportu: výsledky ze zapojení v exportu

○ přjetí exportu: adaptace exportu, zamítnutí exportu

- L. H. Wortzel a H. V. Wortzel (1981) stanovili pět fází procesu expanze na mezinárodní trhy, kdy každá z těchto fází je rozlišitelná mírou kontroly vykonávanou 
exportéry. Základním prvkem této posloupnosti je význam nepředvídaných problémů, které ovlivňují rozhodování o přiměřených a žádoucích úrovních internacionalizačního zapojení. Fáze procesu expanze jsou:

○ táhnutí dovozce

○ základní výrobní marketing

○ pokročilý výrobní marketing

○ produktový marketing - tlak distributora

○ produktový marketing - tah spotřebitele

- M. R. Czinkota (1982) na základě empirického výzkumu odhalil, že firmy v různých fázích internacionalizace jsou významně odlišné $v$ jejich organizačních a manažerských charakteristikách. Czinkota provedl segmentaci firem do šesti skupin:

○ zcela nezajímavé pro firmu

○ částečně zajímavé pro firmu

○ zkoumající firma

○ experimentální firma

○ zkušený malý exportér

○ zkušený velký exportér

- J. S. Lim, T. W. Sharkey a K. I. Kim (1991) rozšírili práci Reida (1981) a identifikovali čtyři úrovně adaptace exportu:

○ uvědomění si exportu

○ zájem o export

- exportní záměr

- adaptace exportu

- T. R. Rao a G. M. Naidu (1992) roztřídili, na základě empirického testování a potvrzení, firmy do jednotlivých skupin podle rozdílných atribut internacionalizačních aktivit firem:

○ neexportéři: firma nemá v současné době žádné exportní aktivity a ani nemá o ně zájem do budoucna

- exportní úmysl: firma v současné době neexportuje, ale ráda by našla v budoucnu exportní př́ležitost

○ nepravidelný exportér: firma exportuje, ale nepravidelně

○ pravidelný exportér: firma exportuje pravidelně

Všechny výše uvedené modely jsou založeny na organizačním učení a jsou odvozovány z fází adaptačního procesu E. M. Rogerse (1962). Adaptace inovace popisuje výběr inovace jako nejlépe přijatelnou alternativu ze skupiny možností v daném čase. Využití systému adaptace inovace v exportním rozhodování poprvé vzali v úvahu Simmonds a Smith (1968), ale poprvé významněji byla tato teorie použita v práci autorů Bilkey a Tesar (1977). Tito autoři dospěli k závěru, že proces vývoje exportu je možno zobrazit několika odlišnými fázemi a že rozhodování v jednotlivých fázích je ovlivněno různými rozličnými faktory. [Morgan, 1997]

\section{Závěr}

Rozhodnutí o internacionalizaci podnikatelských aktivit patří ke klíčovým dlouhodobým strategickým rozhodnutím. Tradiční teorie internacionalizace podnikatelských aktivit nejčastěji vycházejí z teorie Uppsalské školy, která předpokládá, že podniky postupují k internacionalizaci po určitých etapách, krocích. Internacionalizace podniku se tak jeví jako postupný proces akumulace potřebných zdrojů nutných k překonání nejistot na mezinárodních trzích. Evoluční teorie internacionalizace předpokládají, že podniky rostou a sílí na tuzemském trhu a až poté začínají rozvíjet své exportní aktivity. Znalosti a zdroje jsou postupně získávány prostřednictvím zkušeností prvotně na tuzemském trhu a později na trhu 
mezinárodním. Některé podniky nastupují cestu internacionalizace na vyšším vývojovém stupni. Ale mnoho, podniků začíná s internacionalizačními aktivitami velmi krátce po jejich založení. A nejedná se pouze o velké podniky, ale i malé a střední.

Uvedené internacionalizační teorie jsou významné, přestože jejich platnost pozbývá v dnešní době významu. Změny v internacionalizačních teoriích a pozbývání jejich platnosti jsou důsledkem změn v globálním podnikatelském prostředí. Tyto změny se projevují nejen ve změnách podmínek možnosti realizace mezinárodních podnikatelských aktivit, ale také ve stylu managementu podnikatelských subjektů. Management podnikatelských subjektů je silně ovlivněn osobností samotných manažerů a vlastníků. Takže často při rozhodování o realizaci mezinárodních podnikatelských aktivit ani tak nerozhoduje nákladová stránka operací jako spíše osobní zkušenost a odvaha samotných manažerů. A právě s těmito aspekty internacionalizační teorie nepočítají.

\section{Literatura}

[1] ANDERSEN, O. On the Internationalization Process of Firms: a Critical Analysis. In Journal of International Business Studies, 1993, vol. 24, no. 2, p. 209 - 231. ISSN $0047-$ 2506.

[2] JOHANSON, J. - VAHLNE, J.-E. The Internationalization Process of the Firm - A Model of Knowledge Development and Increasing Foreign Market Commitments. In Journal of International Business Studies 1977, vol. 8, no. 1, p. 23 - 32. ISSN 00472506.

[3] JOHANSON, J. - VAHLNE, J.-E. The Uppsala Internationalization Process Model Revisited: From Liability of Foreignness to Liability of Outsidership. In Journal of Internatinal Business Studies 2009, vol. 40, no. 9, p. 1411 - 1431. ISSN 0047-2506.

[4] JOHANSON, J. - WIDERSHEIM-PAUL, F. The Internationalization of the Firm - Four Swedish Cases. In Journal of Management Studies 1975, vol. 12, no. 3, p. 305 - 323. ISSN 1467 - 6786.

[5] LOPEZ, L. E. - KUNDU, S. K. - CIRAVEGNA, L. Born Global or Born Regional? Evidence from an Exploratory Study in the Costa Rican Software Industry. In Journal of International Business Studies 2009, vol. 40, no. 7, p. 1228 - 1238. ISSN 0047-2506.

[6] MORGAN, R. E. - KATSIKEAS, C. S. Theories of International Trade, Foreign Direct Investment and Firm Internationalization: a Critique. In Management Decision 1997, vol. 35, no. 1, p. 68 - 78. ISSN 0021-1747.

[7] RUZZIER, M. - HISRICH, R. D. - ANTONCIC, B. SME Internationalization Reserch: Past, Present, and Future. In Journal of Small Business and Enterprise Development 2006, vol. 13, no. 4, p. 476 - 497, ISSN 1462-6004.

[8] ŠTRACH, P. Mezinárodní management. 1. vyd. Praha: Grada Publishing, 2009. 168 str. ISBN 978-80-247-2987-9..

Klasifikace JEL: M16, F23

\section{Ing. Šárka Zapletalová, Ph.D.}

Katedra managementu a podnikání

Obchodně podnikatelská fakulta v Karviné

Slezská univerzita v Opavě

Univerzitní náměstí 1934/3

73340 Karviná

zapletalova@opf.slu.cz 